\section{SNAP participants' purchasing patterns at a food co-op during the COVID-19 pandemic: A preliminary analysis}

\author{
Molly K. Parker ${ }^{\mathrm{a}}$ and Valisa E. Hedrick ${ }^{\mathrm{b}}$ \\ Virginia Tech
}

Sam Hedges ${ }^{c}$

Local Environmental Agricultural Project

Elizabeth Borst ${ }^{\mathrm{d}}$

Virginia Community Food Connections

Meredith Ledlie Johnson ${ }^{\mathrm{e}}$

Virginia Cooperative Extension, Virginia Tech
SPECIAL ISSUE COSPONSORED BY INFAS: THE IMPACT OF COVID-19 ON FOOD SYSTEMS

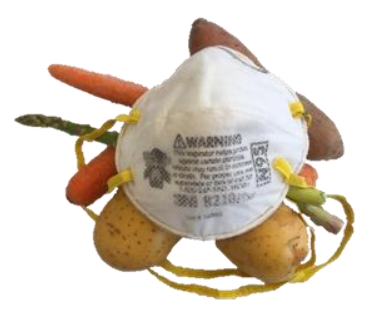

Inter-institutional

Network for

Food and

Agricultural

Sustainability
Maureen McNamara Best ${ }^{\mathrm{f}}$

Local Environmental Agricultural Project

Sarah A. Misyak $\mathrm{g} *$

Virginia Cooperative Extension, Virginia Tech

Submitted September 30, 2020 / Revised January 7 and February 8, 2021 / Accepted February 9, 2021 /

Published online April 1, 2021

Citation: Parker, M. K., Hedrick, V. E., Hedges, S., Borst, E., Ledlie Johnson, M., Best, M. M., \&

Misyak, S. A. (2021). SNAP participants' purchasing patterns at a food co-op during the COVID-

19 pandemic: A preliminary analysis. Journal of Agriculture, Food Systems, and Community Development,

10(2), 147-156. https://doi.org/10.5304/jafscd.2021.102.043

Copyright (C) 2021 by the Authors. Published by the Lyson Center for Civic Agriculture and Food Systems. Open access under CC-BY license.

a Molly K. Parker, MS, Doctoral Student, Virginia Tech; 295
West Campus Drive, 337 Wallace Hall; Blacksburg, VA 24061
USA; +1-540-231-4386; pmolly95@,vt.edu
b Valisa E. Hedrick, PhD, RDN, Assistant Professor, Virginia
Tech; 295 West Campus Drive, 335A Wallace Hall;
Blacksburg, VA 24061 USA; +1-540-231-7983;
vhedrick@,vt.edu

c Sam Hedges, Program Grant Manager, Local Environmental Agricultural Project; P.O. Box 3249; Roanoke, VA 24015 USA; +1-540-632-2295; hedgesjs@leapforlocalfood.org

d Elizabeth Borst, Executive Director, Virginia Community Food Connections; P.O. Box 7664; Fredericksburg, VA 22406 USA; +1-540-845-4267; elizabethborst@gmail.com

${ }^{\mathrm{e}}$ Meredith Ledlie Johnson, MSW, Community Nutrition Coordinator, Virginia Cooperative Extension, Virginia Tech; 295 West Campus Drive, 330 Wallace Hall; Blacksburg, VA 24061 USA; +1-540-231-1704; meredithledlie@,vt.edu

\footnotetext{
${ }^{\mathrm{f}}$ Maureen McNamara Best, MA, Director, Strategic Planning, Local Environmental Agricultural Project; P.O. Box 3249; Roanoke, VA 24015 USA; +1-540-339-6266; maureen@leapforlocalfood.org

g* Corresponding author: Sarah A. Misyak, PhD, MPH, Program Manager for Research and Evaluation, Virginia Cooperative Extension, Virginia Tech; 295 West Campus Drive, 333 Wallace Hall; Blacksburg, VA 24061 USA; +1-540-231-8541; smisyak@vt.edu
}

\section{Author Contributions}

$\mathrm{MP}$ wrote the first draft with contributions from VH, MMB, and SM. All authors reviewed and commented on subsequent drafts of the manuscript and approved the final version.

\section{Funding Disclosure}

This study was funded by a Food Insecurity and Nutrition Incentive program grant through the National Institute for Food and Agriculture of the USDA (USDA-FINI-006104). 


\begin{abstract}
The COVID-19 pandemic has affected the food system, increasing barriers to food access and exacerbating food insecurity across the U.S. The Virginia state government initiated a stay-at- home order to help reduce the spread of COVID-19. Prior to the pandemic, the Virginia Fresh Match (VFM) Nutrition Incentive Network partnered with food retail outlets to provide Supplemental Nutrition Assistance Program (SNAP) participants point-of-purchase incentives (e.g., Double Up Food Bucks, SNAP Match), which function as matching discounts on fresh fruits and vegetables $(\mathrm{F} / \mathrm{V})$. These can enable participants to increase their purchasing power and potentially reduce food insecurity. In response to COVID-19, VFM removed the limit on incentive discounts (previously $\$ 10^{1}$ ) to further incentivize the purchase of fresh F/V by SNAP participants. This study sought to characterize the purchasing patterns of SNAP participants at a food co-operative (co-op) partnered with VFM before and during the Virginia stay-at-home order. A total of 654 transactions at the co-op were included. Independent t-tests were utilized to determine differences before and during the order. The results indicated a significant increase in the mean incentive discount received during the order (pre-shutdown $=\$ 3.95$, inter-shutdown $=\$ 5.01, p=0.035)$; however, simultaneously there was a decrease in the mean number of fresh $\mathrm{F} / \mathrm{V}$ purchased (pre-shutdown $=3.08$, inter-shutdown $=2.39, p=0.015$ ). Although $\mathrm{F} / \mathrm{V}$ purchases decreased, the presence of unlimited point-of-purchase incentives at the food co-op may have helped prevent a greater decline in fresh $\mathrm{F} / \mathrm{V}$ purchases and helped increase access to fresh $\mathrm{F} / \mathrm{V}$ in this population during the onset of the COVID-19 pandemic.
\end{abstract}

\section{Keywords}

Nutrition Incentive Programs, Food System, Food Insecurity, Fruits, Vegetables, SNAP, COVID-19, Pandemic

\section{Introduction}

The spread of COVID-19 and subsequent changes to working conditions and retail environments have had a substantial impact on the food system (Devereux, Béné, \& Hoddinott, 2020; Richards \& Rickard, 2020; Siche, 2020; Singh, Kumar, Panchal, \& Tiwari, 2020), threatening the food supply chain in multiple ways. Consumers have had to shift toward purchasing a greater proportion of their food from retail outlets, partly due to the limitations placed on restaurants and schools in an effort to slow the spread of COVID-19 (Goetz, Schmidt, Chase, \& Kolodinsky, 2020). Sales of food away from home-i.e., foods acquired from restaurants and non-commercial facilities (Elitzak \& Okrent, 2018) — totaled about $\$ 66.9$ billion in January 2020 , and decreased to $\$ 35.7$ billion in April (U.S. Department of Agriculture Economic Research Service [USDA ERS], 2020a). Whereas, sales of food at home-i.e., foods acquired from grocery stores and other food retail outlets (Elitzak \& Okrent, 2018)—increased from about $\$ 65.2$ billion in January to $\$ 69.2$ billion in April, with a large spike in March of $\$ 79.3$ billion (USDA ERS, 2020a). These purchasing behaviors resulted in demand-side shocks to food supply chains, which had difficulty accommodating unexpected surges in demand from consumers (Hobbs, 2020).

High demand for food items at grocery stores coupled with disruptions in the workforce (Artiga \& Rae, 2020; Chadde, 2020; Costa \& Martin, 2020) led to reports of agricultural producers disposing of food items (Newman \& Bunge, 2020) and meatprocessing plants closing due to COVID-19 outbreaks (Gallagher \& Kirkland, 2020) in April. The Food and Drug Administration assured the public there were no food shortages at the national scale (U.S. Food and Drug Administration [US FDA], 2020a). However, many American consumers were concerned about the potential for shortages, when more frequently greeted by empty shelves at grocery stores (US FDA, 2020b). Depleted supplies of grocery store food items can cause greater barriers to accessing adequate food and especially threaten individuals with low incomes who may not be able to find affordable products(Feeding America, 2020; Kinsey, Kinsey, \& Rundle, 2020).

COVID-19 and its impact on the food system

${ }^{1}$ All currency in this paper is US\$. 
have also exacerbated food insecurity (Rami, 2020). The number of households experiencing food insecurity-i.e., unable or uncertain of being able to obtain adequate food during at least part of the year (USDA ERS 2020b)—was expected to rise as a result of COVID-19, especially households with young children, black and Latinx households, and low-income households (Leddy, Weiser, Palar, \& Seligman, 2020). In 2019, 10.5\% of U.S. households experienced food insecurity (USDA ERS, 2020b). Feeding America projected that food insecurity would increase to about $12.5 \%$ of the U.S. population in 2021 (Feeding America, 2021).

Due to the effects of COVID-19, there was an increase in demand for food assistance through SNAP (Leddy et al., 2020), a federal nutrition program that provides low-income families funds to supplement their budget for food (USDA Food and Nutrition Service [USDA FNS], n.d.). To help mitigate the impact of COVID-19 on food insecurity, the Families First Coronavirus Response Act of 2020 allowed states to provide PandemicElectronic Benefits Transfer, temporarily increased SNAP benefits for some individuals and families, and expanded SNAP eligibility criteria (USDA FNS, 2020).

In addition to nutrition assistance programs, nutrition incentive programs provide incentives to SNAP consumers in an effort to increase the amount of fruits and vegetables $(\mathrm{F} / \mathrm{V})$ they purchase (United States Department of Agriculture, National Institute of Food and Agriculture [USDA NIFA], n.d.). Nutrition incentive programs have also been shown to help decrease food insecurity (Durward et al., 2019; Parks, Stern, Fricke, Clausen, \& Yaroch, 2020; Savoie-Roskos, Durward, Jeweks, \& LeBlanc, 2016). The Gus Schumacher Nutrition Incentive Program (GusNIP), formerly the Food Insecurity Nutrition Incentive Program (FINI), is a federal grant program to research and expand nutrition incentive programs (USDA NIFA, n.d.). GusNIP provides funding for programs that help SNAP participants purchase $F / V$ through the use of discounts or matching funds from point-ofpurchase incentives (e.g., Double Up Food Bucks, SNAP Match, Double-Dollar), which are provided to customers at the time and place of purchase (USDA, n.d.). The subject of this study, Virginia
Fresh Match (VFM), is a nutrition incentive network of a number of Virginia farmers markets and food retail outlets that provide nutrition incentives to SNAP customers. VFM is managed by two nonprofit organizations: Local Environmental Agriculture Project and Virginia Community Food Connections (Virginia Fresh Match, n.d.). In 2018, VFM was awarded a $\$ 1.8 \mathrm{M}$ FINI grant to expand the VFM nutrition incentive program at farmers markets and to pilot VFM at neighborhood grocery stores. As of May 2020, Year 3 of the FINI grant, there were 75 outlets offering nutrition incentives, including farmers markets, online farmers market platforms, mobile markets, community supported agriculture programs, and neighborhood grocery stores (e.g., food co-ops).

In response to COVID-19, VFM worked closely with all 75 partner outlets to help them continue to meet community food needs. Prior to COVID-19, these partner outlets offered SNAP participants point-of-purchase incentives as a $50 \%$ discount on fresh F/V with a limit of $\$ 10.00$ in discounts, thus allowing participants up to $\$ 20.00$ worth of fresh $\mathrm{F} / \mathrm{V}$ for the purchase price of $\$ 10.00$. After this limit was reached, participants would pay full price for the remainder of the fresh $\mathrm{F} / \mathrm{V}$ items that they wanted to purchase. As part of the COVID-19 response, VFM allowed all outlets, at their discretion, to increase or remove the $\$ 10.00$ point-of-purchase incentive limit. With VFM eliminating the requirement to limit discounts to $\$ 10.00$, partner outlets were able to further support SNAP customers who may have needed to purchase larger quantities of $\mathrm{F} / \mathrm{V}$ in an effort to stock up or to consolidate shopping trips as ways to decrease their potential exposure to the virus. Other U.S. nutrition incentive programs also removed their limits on incentives as a response to the COVID19 pandemic (Feeding Florida, 2021; Gangwer, 2020). However, no studies have been conducted to see how these may have impacted purchasing patterns of SNAP participants.

With the onset of the COVID-19 pandemic, most states declared restrictions on schools and businesses, with many states mandating closures to non-essential businesses and requiring restaurants to limit operations (Bump, 2020). The governor of Virginia, Dr. Ralph Northam, issued Executive 
Order 55, imposing a temporary stay-at-home order for Virginia and limiting business operations effective March 30, 2020 (Office of the Governor, 2020). Understanding how consumers, particularly vulnerable consumers, immediately respond to major disruptions in the food system, such as those resulting from a broad stay-at-home order, is vital for designing efforts to increase food system resiliency. Therefore, the purpose of this study was to characterize the short-term purchasing patterns of SNAP participants at a food co-op partnered with VFM before and during the onset of the Virginia stay-at-home order.

\section{Methods}

\section{Study Design}

Using a quasi-experimental design, transactions made by SNAP participants at a food co-op were compiled from January 2 through April 30, 2020. The food co-op utilized for this study partnered with VFM to provide SNAP customers point-ofpurchase incentives prior to the onset of the COVID-19 pandemic. Historically, the point-ofpurchase incentive at this food co-op consisted of a $50 \%$ discount on fresh $\mathrm{F} / \mathrm{V}$ with a limit of $\$ 10.00$ in discounts. As of March 27, 2020, the $\$ 10.00$ cap was removed to allow SNAP customers to receive an unlimited amount of point-of-purchase incentive discounts.

\section{Study Site}

The International Cooperative Alliance defines a co-op as "an autonomous association of persons united voluntarily to meet their common economic, social, and cultural needs and aspirations through a jointly owned and democratically controlled enterprise" (2018, para. 3). The food co-op in this study states that they follow the seven cooperative principles outlined by the International Cooperative Alliance: voluntary and open membership; democratic member control; member economic participation; autonomy and independence; education, training, and information; cooperation among cooperatives; and concern for community (International Co-operative Alliance, 2018).

The co-op is located in Harrisonburg, Virginia, a college town with an estimated population of about 53,000 as of 2019 and a 2013 Rural-Urban Continuum Code of 3 , indicating that the region can be considered roughly on the border between metropolitan and non-metropolitan (U.S. Census Bureau, n.d.; USDA ERS, 2013). The co-op is in an area that is considered low-income and low-access at one and twenty miles, meaning that a significant number of residents are over one mile (urban) or 20 miles (rural) from the closest supermarket (USDA ERS, 2020c.) In this region, the majority of the residents are white, and the second largest race/ethnicity group is Hispanic or Latinx. The median household income was $\$ 46,679$ as of 2015 2019 (U.S. Census Bureau, n.d.). In April 2020, 1,837 households in this region received SNAP benefits (Virginia Department of Social Services, 2020). The local retail environment is characterized by several grocery chain locations, a super center, and other small food retailers. Some grocery stores are located near adequate sidewalks and are accessible by pedestrians, but many are only safely accessible through the use of a vehicle. When shopping at the food co-op, customers had access to local products, supplements, produce, bulk items, a bakery, alcoholic beverages, meats, a deli, and a hot bar. Standard SNAP rules and regulations applied to items purchased at the food co-op and incentives could only be used on fresh F/V (i.e., F/V that were not canned or frozen, and fresh herbs).

\section{Data Collection}

Transaction data were compiled from computer receipts that were collected and stored by the food co-op at the time of purchase. The data consisted of the date each purchase was completed, a description of each item purchased, the cost of each item, the payment method(s) used, and the amount that was discounted in the form of pointof-purchase incentives. The receipts were used to estimate the number of unique SNAP customers. No identifier data were collected and no data were collected directly from customers. In accordance with the Virginia stay-at-home order, transactions made before March 30, 2020 were coded as preshutdown and those made on and after March 30, 2020, were coded as inter-shutdown. Transactions considered returns or refunds were excluded from analysis. This project was determined not to be 
human subjects research by the Western Institutional Review Board.

\section{Statistical Analysis}

Statistical data were generated using IBM SPSS 26.0 statistical software. Descriptive statistics were performed to determine the frequencies of variables, including purchases and fresh F/V items. Independent t-tests were used to analyze statistical differences between pre-shutdown and inter-shutdown purchases for the following variables: the amount of SNAP benefits spent, the amount spent on the entire purchase, the total number of items purchased, the gross price of fresh $\mathrm{F} / \mathrm{V}$ items purchased, the number of fresh $\mathrm{F} / \mathrm{V}$ items purchased, the percentage of fresh $\mathrm{F} / \mathrm{V}$ items purchased in relation to all items purchased, the gross cost of all fresh $\mathrm{F} / \mathrm{V}$ items per purchase, and the amount of money discounted from point-of-purchase incentives. Significance was set a priori as $\mathrm{p} \leq 0.05$.

\section{Results}

The total number of transactions from SNAP customers at the food co-op from May 2019 through April 2020 was 2,836, totaling $\$ 40,669.60$. For this study, 654 transactions from SNAP customers were analyzed, of which 403 were completed preshutdown and 251 were completed inter-shutdown. It was estimated that 184 unique SNAP customers completed the transactions.

The 654 purchases totaled $\$ 14,600.37$, with $\$ 12,784.74$ spent in SNAP benefits. A total of 435 transactions included discounts from point-of-purchase incentives, generating $\$ 2,850.54$ in discounts. After the discounts, a total of $\$ 3,836.57$ was spent in SNAP benefits on fresh $\mathrm{F} / \mathrm{V}$ items. Over the course of the study, the included transactions at the food co-op increased from $\$ 1,926.22$ in January to $\$ 5,834.06$ in April. The monthly amount spent in SNAP benefits also generally followed this positive trend, from $\$ 1,823.83$ in January to $\$ 5,310.66$ in April. In addition, the total number of monthly SNAP transactions more than doubled, from 105 in January to 242 in April.

Pre-shutdown, a total of 1,240 fresh F/V items were purchased $(84.1 \%$ of purchases contained fresh $\mathrm{F} / \mathrm{V}$ items, and $46.3 \%$ of purchased items were fresh $\mathrm{F} / \mathrm{V}$ ), with some of the most common including organic bananas, pints of blueberries, and organic avocados. Items coded as miscellaneous bulk produce, price-reduced produce, and general produce at the food co-op were also among the most commonly purchased items. Inter-shutdown, a total of 600 fresh $\mathrm{F} / \mathrm{V}$ items were purchased (57.8\% of purchases contained fresh $\mathrm{F} / \mathrm{V}$ items, and $36.3 \%$ of purchased items were fresh F/V). Of the 600 fresh F/V items, some of the most frequently purchased were organic bananas, tomatoes, organic avocados, and regular avocados. When comparing the mean gross price of fresh $\mathrm{F} / \mathrm{V}$ items purchased pre-shutdown with inter-shutdown, the gross price inter-shutdown was significantly higher at $\$ 4.22 \pm 2.36$ compared to preshutdown at $\$ 3.38 \pm 1.95(p \leq 0.001)$.

The mean number of fresh $\mathrm{F} / \mathrm{V}$ items purchased and the mean percentage of fresh $\mathrm{F} / \mathrm{V}$ items purchased in relation to all items purchased were both significantly lower during inter-shutdown as compared to pre-shutdown $(p<0.05)$; however, the mean amount of money discounted from point-of-purchase incentives was found to be significantly higher during inter-shutdown $(p<0.05)$, with a maximum discount received of $\$ 44.88$ (see Table).

\section{Discussion}

The significant reduction in the number of fresh $\mathrm{F} / \mathrm{V}$ items SNAP participants purchased intershutdown, both in count and as a percentage of all items purchased, may indicate that the stay-athome order influenced purchasing patterns. Although there is limited data from which to draw conclusions as to the plausible causes of these differences, the results demonstrate that there was a significant increase in the mean gross price of fresh $\mathrm{F} / \mathrm{V}$ items purchased and there was not a significant change in the gross cost of fresh $\mathrm{F} / \mathrm{V}$ items per transaction, signaling that the significant decrease could be the result of customers balancing the cost of the fresh F/V items with the quantity due to budgetary concerns. This was further exemplified by the changes in the most commonly purchased types of fresh F/V items. An additional explanation for the decline in the number of fresh $\mathrm{F} / \mathrm{V}$ items purchased is that some households may have prioritized shelf-stable F/V items, like canned 
Table. Differences in SNAP Purchases made Pre-shutdown And Inter-shutdown Secondary to COVID-19 a

\begin{tabular}{|c|c|c|c|c|c|c|c|}
\hline \multirow[b]{2}{*}{ Transaction Details } & \multicolumn{2}{|c|}{$\begin{array}{l}\text { Pre-shutdown Purchases } \\
\qquad(n=403)\end{array}$} & \multicolumn{2}{|c|}{$\begin{array}{l}\text { Inter-shutdown Purchases } \\
\qquad(n=251)\end{array}$} & \multicolumn{2}{|c|}{ Mean Difference } & \multirow{2}{*}{$\begin{array}{c}\text { Significance } \\
p_{\text {-value }}{ }^{c}\end{array}$} \\
\hline & Mean & (SD) & Mean & (SD) & Mean & (SE) & \\
\hline SNAP Spent (\$) & 19.18 & $(27.49)$ & 22.22 & $(29.60)$ & 3.04 & $(2.28)$ & 0.182 \\
\hline Transaction Total $(\$)$ & 21.29 & $(29.80)$ & 24.47 & $(32.30)$ & 3.17 & $(2.48)$ & 0.200 \\
\hline Total Items Purchased (n) & 6.64 & $(7.13)$ & 6.58 & $(7.70)$ & -0.06 & $(0.59)$ & 0.916 \\
\hline Gross F/V Cost $(\$)$ & 10.30 & $(11.32)$ & 10.10 & $(16.97)$ & -0.20 & $(1.11)$ & 0.857 \\
\hline F/V Items Purchased (n) & 3.08 & $(3.26)$ & 2.39 & $(3.86)$ & -0.69 & $(0.28)$ & 0.015 \\
\hline F/V Items vs. Total Items (\%) & 56.35 & $(39.55)$ & 33.19 & (37.15) & -23.16 & (3.11) & $<0.001$ \\
\hline Incentive Discount (\$) $\mathrm{b}$ & 3.95 & $(3.74)$ & 5.01 & $(8.84)$ & 1.05 & $(0.50)$ & 0.035 \\
\hline
\end{tabular}

a SNAP: Supplemental Nutrition Assistance Program; F/V: Fresh fruits and vegetables

b In pre-shutdown, the discount from point-of-purchase incentives was capped at \$10; in inter-shutdown the cap was lifted.

${ }^{c}$ Bold $p$-values indicate significance.

and frozen options (Cranfield, 2020). However, data on purchases of canned and frozen $\mathrm{F} / \mathrm{V}$ were not compiled in this study. Consumers could have also shifted their purchasing patterns because of perceived shortages in food supply, due to reports of low or empty stock of certain items at food retailers over the course of the pandemic (U.S. FDA, 2020a). These potential explanations cannot be tested in the present study because no personal information or survey data was collected. Other unknown environmental factors may have also impacted the purchasing behaviors demonstrated by the data, and significant changes in purchases might have occurred prior to the stay-at-home order. As these data are from one food co-op, the results may not be generalizable. In addition, the research team was unable to compare the sales data from the food co-op during the same time frame for the previous year (January-April 2019) or to overall store purchases. Although these are limitations, the focus of this study was to analyze the immediate impacts of the stay-at-home order on SNAP purchases at the food co-op, which was accomplished through assessing transactions preand inter-shutdown between January and April 2020.

The overall increase in the total amount spent at the co-op during inter-shutdown is representative of the data that has found that household spending at grocery stores increased compared to earlier in 2020 (Baker, Farrokhnia, Meyer, Pagel, \&
Yannelis, 2020). The current findings also demonstrate a significant increase in the mean amount of money individuals received in discounts from point-of-purchase incentives. This was expected due to the removal of the incentive cap as of March 27, 2020. Previous research has shown point-of-purchase incentives can increase $\mathrm{F} / \mathrm{V}$ purchases (Polacsek et al., 2018; Steele-Adjognon $\&$ Weatherspoon, 2017); therefore, access to these incentives during a time of heightened food insecurity might have helped to prevent a more substantial decline in fresh F/V purchases by SNAP participants. No formal advertising or marketing for the incentive cap removal had been conducted at the time of the study, but some customers purchased fresh $\mathrm{F} / \mathrm{V}$ items in quantities that allowed for a significantly increased mean discount. This may demonstrate that some customers were buying larger quantities of fresh $\mathrm{F} / \mathrm{V}$ items in order to stock up due to the stay-at-home order in Virginia, with the point-of-purchase incentives helping to reduce the financial burden of this change in purchasing behaviors. The presence of point-ofpurchase incentives at the co-op may have also helped to lessen food insecurity for SNAP participants, as these types of incentives have been shown to do in previous research (Durward et al., 2019; Parks et al., 2020; Savoie-Roskos et al., 2016).

An advantage of nutrition incentive programs during crises such as COVID-19 is their ability to increase food purchasing power while other emer- 
gency food programs may be experiencing disruptions. COVID-19 exposed vulnerabilities in the food bank distribution system, with food banks experiencing difficulty maintaining adequate stock once donations waned (Bublitz, Czarkowski, Hansen, Peracchio, \& Tussler, 2020). There was also an increased demand for food bank services and a shortage of volunteers (Kulish, 2020). Nutrition incentive programs did not face these same challenges, and accordingly demonstrated the ability to quickly respond to COVID-19 and provide SNAP participants the opportunity to consistently purchase additional fresh $\mathrm{F} / \mathrm{V}$ items.

Interest in local foods may increase in response to COVID-19 (Hobbs, 2020). When responding to the pandemic, retailers selling local food items may have an advantage maintaining their stock because their supply chains are not fully dependent on imports or interstate commerce, which may experience disruptions more readily. Consumers may also experience stronger motivation to support local economies, due to COVID-19 (Hobbs, 2020). Indeed, some community-supported agriculture programs and farmers markets experienced heightened sales during the early stages of the COVID-19 pan demic (Kolodinsky, Sitaker, Chase, D, \& Wang, 2020). However, smaller food retailers selling local foods, such as the co-op in this study, may be unable to offer a wide variety of products in ways that are as cost-effective as larger grocery store chains (Hobbs, 2020). Considering that the pandemic resulted in job losses and reduced incomes (Board of Governors of the Federal Reserve, 2020), many individuals might have sought more affordable food options at larger grocery chains. Cost-effective products may have been especially crucial to SNAP consumers during the pandemic, given the importance of prices and sales on their food purchasing decisions (Mabli \& Worthington, 2015). The present study did not assess changes in local food purchases at the food co-op.

These findings provide support for increased point-of-purchase incentive discounts as a way to encourage SNAP customers to buy fresh $\mathrm{F} / \mathrm{V}$ items from food co-ops. This form of response to COVID-19 and future crises might help maintain local businesses and farmer/producer operations while improving access to fresh $\mathrm{F} / \mathrm{V}$ items.

\section{Conclusions}

This has been the first study to examine changes in the purchasing patterns of SNAP participants during the initial phase of a COVID-19 stay-athome order. Overall, the results indicate that total monthly sales increased at the food co-op after the initiation of the Virginia order in April. Customers significantly reduced the number of fresh $\mathrm{F} / \mathrm{V}$ items they purchased, which may have been the result of consumers desiring shelf-stable products or purchasing different types of fresh $\mathrm{F} / \mathrm{V}$ items that were less cost-effective.

The results of this study demonstrate how the Virginia stay-at-home order immediately impacted food purchasing at the food co-op, providing insight into how SNAP participants responded to the abrupt change- or their fear of change-in the food supply chain. Other studies should assess the long-term impacts that COVID-19 may have on the food purchasing patterns of SNAP participants. Future research should also directly investigate the potential impact that COVID-19 may have on local food purchases. Additionally, qualitative data collection from customers would help determine the decision-making processes and motivations behind the behavior changes demonstrated in this study. It is expected that many consumers will revert to preCOVID-19 behaviors, but some behavior changes may remain (Sheth, 2020), and this study provides important baseline results, allowing for the future comparison of short-term and long-term COVID19 impacts.

This study provides preliminary evidence that nutrition assistance programs, such as SNAP, and incentive programs funded by GusNIP, like VFM, may act as buffers to shifts in consumer purchasing patterns in response to the volatility of the food system, as has been seen during the COVID-19 pandemic.

\section{Acknowledgments}

We would like to thank Sydney Crofton and Catherine Trejo for assisting with data entry.

(see References, next page) 


\section{References}

Artiga, S., \& Rae, M. (2020, June 2). The COVID-19 outbreak and food production workers: Who is at risk? San Francisco, CA \& Washington, D.C.: Kaiser Family Foundation. https://www.kff.org/coronavirus-covid-19/issuebrief/the-covid-19-outbreak-and-food-production-workers-who-is-at-risk/

Baker, S. R., Farrokhnia, R. A., Meyer, S., Pagel, M., \& Yannelis, C. (2020). How does household spending respond to an epidemic? Consumption during the 2020 COVID-19 pandemic. The Review of Asset Pricing Studies, 10(4), 834-862. https://doi.org/10.1093/rapstu/raaa009

Board of Governors of the Federal Reserve. (2020). Report on the economic well-being of U.S. households in $2019-$ May 2020. Washington, D.C.: Federal Reserve System. https://www.federalreserve.gov/publications/2020-economic-wellbeing-of-us-households-in-2019-financial-repercussions-from-covid-19.htm

Bublitz, M. G., Czarkowski, N., Hansen, J., Peracchio, L. A., \& Tussler, S. (2020). Pandemic reveals vulnerabilities in food access: Confronting hunger amidst a crisis. Journal of Public Policy \& Marketing, 40(1), 105-107. https://doi.org/10.1177/0743915620929998

Bump, P. (2020, March 17). Mapping where America has been shut down. The Washington Post. https://www.washingtonpost.com/politics/2020/03/17/mapping-where-america-has-been-shut-down/

Chadde, S. (2020, April 16). Tracking COVID-19's impact on meatpacking workers and industry [Online newsroom]. Champaign, IL: Midwest Center for Investigative Reporting. https://investigatemidwest.org/2020/04/16/tracking-covid-19s-impact-on-meatpacking-workers-and-industry/

Costa, D., \& Martin, P. (2020). Coronavirus and farmworkers: Farm employment, safety issues, and the H-2A guestworker program. Washington, D.C.: Economic Policy Institute. https://www.epi.org/publication/coronavirus-and-farmworkers-h-2a/

Cranfield, J. A. L. (2020). Framing consumer food demand responses in a viral pandemic. Canadian Journal of Agricultural Economics/Revue Canadienne d'Agroeconomie, 68(2), 151-156. https://doi.org/10.1111/cjag.12246

Devereux, S., Béné, C., \& Hoddinott, J. (2020). Conceptualising COVID-19's impacts on household food security. Food Security, 12, 769-772. https://doi.org/10.1007/s12571-020-01085-0

Durward, C. M., Savoie-Roskos, M., Atoloye, A., Isabella, P., Jewkes, M. D., Ralls, B., . . LeBlanc, H. (2019). Double Up Food Bucks participation is associated with increased fruit and vegetable consumption and food security among lowincome adults. Journal of Nutrition Education and Behavior, 51(3), P342-P347. https://doi.org/10.1016/j.jneb.2018.08.011

Elitzak, H., \& Okrent, A. (2018). New U.S. food expenditure estimates find food-away-from-home spending is higher than previous estimates [Amber $W$ aves, online ERS magazine]. Washington, DC: USDA, Economic Research Service. https://www.ers.usda.gov/amber-waves/2018/november/new-us-food-expenditure-estimates-find-foodaway-from-home-spending-is-higher-than-previous-estimates/

Feeding America. (2020, rev. April 22). The impact of the coronavirus on food insecurity. Chicago: Feeding America. https://www.feedingamerica.org/sites/default/ files/202004/Brief Impact $\% 20$ of $\% 20$ Covid $\% 20$ on $\% 20$ Food $\% 20$ Insecurity $\% 204.22 \% 20 \% 28002 \% 29 . p d f$

Feeding America. (2021, March). The impact of the coronavirus on food insecurity in 2020 and 2021. Chicago: Feeding America. https://www.feedingamerica.org/sites/default/files/2021-03/National\%20Projections\%20Brief 3.9.2021 0.pdf

Feeding Florida. (2021). How to double your SNAP/EBT for Florida-grown produce with Fresh Access Bucks. Tallahassee, FL: Feeding Florida. https://www.feedingflorida.org/food-access/fresh-access-bucks/how-fab-works

Gallagher, D., \& Kirkland, P. (2020, April 27). Meat processing plants across the US are closing due to the pandemic. Will consumers feel the impact? CNN Business. https://www.cnn.com/2020/04/26/business/meat-processing-plants-coronavirus/index.html

Gangwer, K. (2020). Produce Perks Midwest increases unlimited \$1:\$1 SNAP match to support vulnerable families during COVID-19. Cincinnati, OH: Produce Perks Midwest. https://produceperks.org/2020/03/produce-perks-midwest-increasesunlimited-11-snap-match-to-support-vulnerable-families-during-covid-19/

Goetz, S., Schmidt, C., Chase, L., \& Kolodinsky, J. (2020). Americans' food spending patterns explain devastating impact of COVID-19 lockdowns on agriculture. Journal of Agriculture, Food Systems, and Community Development, 9(3), 31-33. https://doi.org/10.5304/jafscd.2020.093.033 
Hobbs, J. E. (2020). Food supply chains during the COVID-19 pandemic. Canadian Journal of Agricultural Economics/Revue Canadienne d'Agroeconomie, 68(2), 171-176. https://doi.org/10.1111/cjag.12237

International Co-operative Alliance. (2018). Cooperative identity, values \& principles. Brussels: ICA. https://www.ica.coop/en/cooperatives/cooperative-identity

Kinsey, E. W., Kinsey, D., \& Rundle, A. G. (2020). COVID-19 and food insecurity: An uneven patchwork of responses [Editorial]. Journal of Urban Health, 97(3), 332-335. https://doi.org/10.1007/s11524-020-00455-5

Kolodinsky, J., Sitaker, M., Chase, L., Smith, D., \& Wang, W. (2020). Food systems disruptions: Turning a threat into an opportunity for local food systems. Journal of Agriculture, Food Systems, and Community Development, 9(3), 5-8. https://doi.org/10.5304/jafscd.2020.093.013

Kulish, N. (2020, April 8). 'Never seen anything like it': Cars line up for miles at food banks. The New York Times. https://www.nytimes.com/2020/04/08/business/economy/coronavirus-food-banks.html

Leddy, A. M., Weiser, S. D., Palar, K., \& Seligman, H. (2020). A conceptual model for understanding the rapid COVID19-related increase in food insecurity and its impact on health and healthcare. The American Journal of Clinical Nutrition, 112(5), 1162-1169. https://doi.org/10.1093/ajen/nqaa226

Mabli, J., \& Worthington, J. (2015). The food access environment and food purchase behavior of SNAP households. Journal of Hunger \& Environmental Nutrition, 10(1), 132-149. https://doi.org/10.1080/19320248.2015.1004221

Newman, J., \& Bunge, J. (2020, April 9). Farmers dump milk, break eggs as coronavirus restaurant closings destroy demand. The Wall Street Journal. https://www.wsj.com/articles/farmers-deal-with-glut-of-food-as-coronavirus-closes-restaurants-11586439722

Office of the Governor, Commonwealth of Virginia. (2020, March 30). Executive Order Number Fifty-Five (2020). Temporary stay at home order due to novel coronavirus (COVID-19). Richmond, VA: Office of the Governor. https://www.governor.virginia.gov/media/governorvirginiagov/executive-actions/EO-55-Temporary-Stay-atHome-Order-Due-to-Novel-Coronavirus-(COVID-19).pdf

Parks, C. A., Stern, K. L., Fricke, H. E., Clausen, W., \& Yaroch, A. L. (2020). Healthy food incentive programs: Findings from food insecurity nutrition incentive programs across the United States. Health Promotion Practice, 21(3), 421-429. https://doi.org/10.1177/1524839919898207

Polacsek, M., Moran, A., Thorndike, A. N., Boulos, R., Franckle, R. L., Greene, J. C., . . Rimm, E. B. (2018). A supermarket double-dollar incentive program increases purchases of fresh fruits and vegetables among low-income families with children: The healthy double study. Journal of Nutrition Education and Behavior, 50(3), P217-228.E1. https://doi.org/10.1016/j.jneb.2017.09.013

Rami, Z. (2020). Pandemic and food security: A view from the global South. Journal of Agriculture, Food Systems, and Community Development, 9(3), 17-21. https://doi.org/10.5304/jafscd.2020.093.014

Richards, T. J., \& Rickard, B. (2020). COVID-19 impact on fruit and vegetable markets. Canadian Journal of Agricultural Economics/Revue Canadienne d'Agroeconomie, 68(2), 189-194. https://doi.org/10.1111/cjag.12231

Savoie-Roskos, M., Durward, C., Jeweks, M., \& LeBlanc, H. (2016). Reducing food insecurity and improving fruit and vegetable intake among farmers' market incentive program participants. Journal of Nutrition Education and Behavior, 48(1), P70-76.E1. https://doi.org/10.1016/i.jneb.2015.10.003

Sheth, J. (2020). Impact of Covid-19 on consumer behavior: Will the old habits return or die? Journal of Business Research, 117, 280-283. https://doi.org/10.1016/j.jbusres.2020.05.059

Siche, R. (2020). What is the impact of COVID-19 disease on agriculture? Scientia Agropecuaria, 11(1), 3-6. https://doi.org/10.17268/sci.agropecu.2020.01.00

Singh, S., Kumar, R., Panchal, R., \& Tiwari, M. K. (2020). Impact of COVID-19 on logistics systems and disruptions in food supply chain. International Journal of Production Research [In press]. https://doi.org/10.1080/00207543.2020.1792000

Steele-Adjognon, M., \& Weatherspoon, D. (2017). Double Up Food Bucks program effects on SNAP recipients' fruit and vegetable purchases. BMC Public Health, 17(1), Art. 946. https://doi.org/10.1186/s12889-017-4942-Z

U.S. Census Bureau. (n.d.). QuickFacts. Harrisonburg, VA. 2010-2019. https://www.census.gov/quickfacts/fact/table/harrisonburgcityvirginiacounty,US/PST045219 
U.S. Department of Agriculture Economic Research Service [USDA ERS]. (2013). Rural-urban continuum codes. https://www.ers.usda.gov/data-products/rural-urban-continuum-codes/

USDA ERS. (2020a). Food expenditure series. https://www.ers.usda.gov/data-products/food-expenditure-series/

USDA ERS. (2020b). Food security status of U.S. households in 2019. https://www.ers.usda.gov/topics/food-nutritionassistance/food-security-in-the-us/key-statistics-graphics.aspx\#foodsecure

USDA ERS (2020c). Food access research atlas. https://www.ers.usda.gov/data-products/food-access-research-atlas/

USDA Food and Nutrition Service [USDA FNS]. (n.d.). Supplemental Nutrition Assistance Program (SNAP). https://www.fns.usda.gov/snap/supplemental-nutrition-assistance-program

USDA FNS. (2020, April 22). USD A increases monthly SNAP benefits by 40\%: Emergency benefits prompted by COVID-19 [Press release]. https://www.fns.usda.gov/news-item/usda-022720

USDA National Institute of Food and Agriculture. (n.d.). Gus Schumacher Nutrition Incentive Program. https://nifa.usda.gov/program/gus-schumacher-nutrition-incentive-grant-program

U.S. Food and Drug Administration. (2020a, April 1). Food safety and availability during the coronavirus pandemic [Consumer update]. https:/ / www.fda.gov/consumers/consumer-updates/food-safety-and-availability-during-coronavirus-pandemic

U.S. Food and Drug Administration. (2020b, April 16). FDA's perspective on food safety and availability during and beyond COVID-19. https://www.fda.gov/food/conversations-experts-food-topics/fdas-perspective-food-safety-andavailability-during-and-beyond-covid-19

Virginia Department of Social Services. (2020). SNAP participation reports. Richmond, VA: Virginia Department of Social Services. https://www.dss.virginia.gov/geninfo/reports/financial assistance/fs.cgi

Virginia Fresh Match. (n.d.). Virginia Fresh Match: A statewide network to belp farmers markets serve low-income shoppers. Midlothian, VA: Virginia Fresh Match. https://vfm.leapforlocalfood.org/about-us/ 